\title{
Health service use among children with and without eczema, asthma, and hay fever
}

This article was published in the following Dove Press journal:

Clinical Epidemiology

13 September 2016

Number of times this article has been viewed

\author{
Lene Hammer-Helmich ${ }^{1,2}$ \\ Allan Linneberg $1,3,4$ \\ Simon Francis Thomsen ${ }^{5,6}$ \\ Line Tang' \\ Charlotte Glümer ${ }^{1,7}$ \\ 'Research Center for Prevention \\ and Health, The Capital Region of \\ Denmark, Copenhagen, ${ }^{2}$ Department \\ of Real World Evidence and \\ Epidemiology, H. Lundbeck A/S, Valby, \\ ${ }^{3}$ Department of Clinical Experimental \\ Research, Rigshospitalet, ${ }^{4}$ Department \\ of Clinical Medicine, Faculty of Health \\ and Medical Sciences, University \\ of Copenhagen, ${ }^{5}$ Department of \\ Dermatology, Bispebjerg Hospital, \\ ${ }^{6}$ Department of Biomedical Sciences, \\ Faculty of Health and Medical \\ Sciences, University of Copenhagen, \\ Copenhagen, ${ }^{7}$ Department of Health \\ Science and Technology, Faculty of \\ Medicine, Aalborg University, Aalborg, \\ Denmark
}

Correspondence: Allan Linneberg Research Centre for Prevention and Health, Centre for Health, The Capital Region of Denmark, Nordre Ringvej 57, Afsnit 84/84, 2600 Glostrup, Denmark Tel +4530633260

Email allan.linneberg@regionh.dk
Background: Atopic diseases, for example, eczema, asthma, and hay fever, are among the most common chronic diseases of childhood. Knowledge on health service use among children with atopic disease is limited. This study aimed to investigate the total use and costs of health services for children with and without eczema, asthma, and hay fever in a Danish general population.

Methods: We conducted a health survey with four complete birth cohorts from the City of Copenhagen. Individual questionnaire data on eczema, asthma, and hay fever for children aged $3,6,11$, and 15 years were linked to register information on use and costs of health services and prescribed medication and parental education. In total 9,720 children participated (50.5\%). Results: We found increased health service use (number of additional consultations per year [95\% confidence interval]) among children with current eczema symptoms (1.77 [1.29-2.26]), current asthma symptoms (2.53 [2.08-2.98]), and current hay fever symptoms (1.21 [0.74-1.67]), compared with children without these symptoms. We also found increased use of prescribed medication and most subtypes of health services. Current asthma symptoms and current eczema symptoms, but not current hay fever symptoms, increased the health service costs with at least $€ 300$ per year per child.

Conclusion: Children with eczema, asthma, and hay fever used health services and prescribed medication more than children without these diseases.

Keywords: asthma, atopic dermatitis, costs, hay fever, health services

\section{Introduction}

Eczema, asthma, and hay fever are among the most common chronic diseases of childhood. As they are all associated with atopy, that is, the propensity to develop an IgE-mediated immune response to environmental allergens, they are often referred to as the atopic diseases. Several studies have examined asthma-related health service use among children with asthma, comparing, for example, ethnic minority children vs Caucasians, ${ }^{1}$ children with suboptimal vs optimal medication regimens, ${ }^{2}$ children with public vs private health insurances, ${ }^{3}$ or children of single vs married parents. ${ }^{4}$ However, total health service use among children with asthma or eczema compared with children without these diseases is scarcely described, and studies from countries with universal health care access are rare.

A French study found increased use of prescribed medication and higher costs of general practitioner consultations and prescribed medication among children with atopic eczema compared with healthy controls. ${ }^{5}$ A Canadian and a German study found increased likelihood of consultations with the general practitioner and of hospitalization among children with asthma compared with children without. ${ }^{6,7}$ 
Finally, an American study of children with the same insurance found increased odds of using prescribed medication, outpatient hospital visits, emergency department visits, and hospitalization among children with asthma compared with children without. ${ }^{8}$ We are not aware of any studies assessing health service use among children with hay fever or rhinitis compared with children without.

Due to high-quality, national registers providing access to administrative data for researchers, it is possible in Denmark to examine health service use and costs in detail at the individual level. ${ }^{9}$

The aim of this study was to examine use and costs of health services for children with and without eczema, asthma, and hay fever.

\section{Methods}

\section{Study population and design}

The study was based on a cross-sectional child health survey described in detail elsewhere, ${ }^{10}$ including all children born in 1994, 1998, 2003, or 2006, who were resident in the City of Copenhagen in September 2009. Children aged 11 or 15 years answered questionnaires themselves, whereas the parents answered for children aged 3 or 6 years. We linked questionnaire data to administrative registers on demographics, health service use and costs, prescribed medication use and costs, and the primary carer's education. Statistics Denmark provided register data linked by the unique personal identification number, the CPR number. ${ }^{11}$ Register data were available for all the invited children.

In total, 9,720 out of 19,241 invited children participated $(50.5 \%)$, with the lowest response rate among children aged 15 years (42.4\%), followed by children aged 11 $(50.9 \%), 6(51.0 \%)$, and 3 years $(55.2 \%)$. Most parents gave written, informed consent for participation when returning the questionnaires. For the 1,043 questionnaires returned without a signature, the Danish Data Protection Agency gave permission to consider having followed the written instructions and returned the questionnaire as informed consent. The study was approved by the Danish Data Protection Agency. According to Danish legislation, approval from the Danish Health Research Ethics Committee System is not required for studies based solely on questionnaires and registers.

\section{Eczema, asthma, and hay fever}

Outcome measures were eczema, asthma, and hay fever discerned as "known disease ever" and "current symptoms". The measures were adapted from the International Study of
Asthma and Allergies in Childhood, ${ }^{12}$ and eczema symptoms were defined according to the United Kingdom Working Party's diagnostic criteria. ${ }^{13}$ Known disease ever was defined as "yes" to a single question for each disease, as were current asthma and hay fever symptoms. Current eczema symptoms were defined as "yes" to one major criterion and at least two of four minor criteria. The definitions are described in detail elsewhere. ${ }^{10}$

\section{Health service use}

Denmark has a tax-funded health care system with health services free of charge for any person resident in Denmark and partial reimbursement for prescribed medication. ${ }^{14}$

Total health service use in 1 year, 2009, was calculated as the sum of all consultations in the primary and secondary health care sector. In primary health care, this included any consultation with a general practitioner or medical specialist, and also approved email and telephone consultations and after-hours duty doctor services. In secondary (or tertiary) health care, this included all outpatient hospital visits, emergency department visits, and hospital admissions in the somatic and psychiatric system.

Subtypes of health services were dichotomized as whether or not the child had used the service during 2009: general practitioner, atopic disease-relevant medical specialist (ie, dermatologist; internal medicine specialist; ophthalmologist; ortho-, rhino-, and laryngologist; or pediatrician), and after-hours duty doctor. Outpatient hospital, emergency department, and hospital admissions were given with additional variables for atopic diseaserelated visits (ICD-10 codes: L20 [atopic eczema], J45, J46 [asthma], J30.0-4, H10.0 [allergic rhinitis]) and infection-related visits (A02-A09 [gastrointestinal infections], A30-49 [other bacterial infections], A80, A81, A85-A89 [viral infections in central nervous system], B00-B09, B25-B49, B95-B99 [other infectious diseases], H60, H65-H68, H70-H72, H75, H92 [ear infections], J00-J22, J32, J35.0, J36, J40-J42, J85, J86 [respiratory infections], L00-L08 [skin infections], N00, N01, N30, N39.0 [urinary tract infections], R50, R560 [fever of other and unknown causes]).

Total use of prescribed medication was calculated as total number of collected packages of prescribed medication for the child during 2009. Subtypes of prescribed medication were dichotomized as whether or not any medication of the following types was collected: skin medication (ACT codes: D01-D04, D05AA, D06-D08), respiratory or eye medication (R01, R03, R05, R06, S01G), systemic hormones 
(H02A), and anti-infective medication (J01-J05, D06, D08, S01A).

Total health service costs were calculated for 2009 as the total individual-level costs of all health services held by the tax-funded health care system including primary and secondary (tertiary) services and total costs of any prescribed medication. Subtypes of costs were additionally calculated as costs of prescribed medication and patient share of prescribed medication. Total and subtypes of costs of health services were derived from registers where exact prices of primary health care, prescribed medications, and diagnosis-related group tariffs are recorded. ${ }^{15}$

\section{Primary carer's education}

The primary carer's highest attained educational level as of October 2009 was divided into four categories: 1) master's degree or higher, 2) bachelor or academy degree, 3) vocational training, and 4) primary/secondary school including lower secondary school and general upper secondary education. The primary carer was defined as the mother, except in the cases where the father had full custody of the child.

\section{Statistical analyses}

We analyzed total health service use, prescribed medication use, and costs for children with each atopic disease or symptom group separately compared with children without, and adjusted for sex, age, and the primary carer's educational level. We used linear regression analyses with maximum likelihood estimates, 95\% confidence intervals (CIs), and test of significance.

We analyzed each subtype of health service and prescribed medication by logistic regression analyses with maximum likelihood estimation of odds ratios, $95 \% \mathrm{CIs}$, and test of significance, and with the same adjustments as mentioned.

Data were weighted for nonresponse based on register information on sex, age, ethnicity, health service use, parental civil status, parental educational level, household income, and type of residence in order to increase representativity. ${ }^{16}$ The weights were computed by Statistics Denmark. ${ }^{17} \mathrm{We}$ also performed analyses without weighing for nonresponse, and the results were essentially the same. All analyses were performed in SAS statistical software version 9.3 (SAS Institute Inc., Cary, NC, USA), using their survey procedures. Statistical significance was defined as $P<0.05$.

\section{Results}

Descriptives of the population have been published previously. ${ }^{10}$ In total, 9,720 children participated. $50.3 \%$ were female, and $35.3 \%, 25.8 \%, 21.3 \%$, and $17.6 \%$ of the sample were $3,6,11$, and 15 years old, respectively. The prevalence of current symptoms was $9.5 \%$ for eczema, $11.6 \%$ for asthma, and $10.9 \%$ for hay fever (Table 1).

\section{Total health service use and costs}

Children in the study had, on average, six consultations with the health care system and used two packages of prescribed medication, and these services cost $€ 600$ per year (Table 1 ). These figures varied slightly in different subgroups of children. Children aged 3 years had two more annual consultations than the other age groups, while children aged 15 years used most prescribed medication and had the highest health service costs.

All atopic diseases and symptoms were associated with increased use of health services and prescribed medication, also when adjusted for sex, age, and primary carer's educational level (Table 2). Children with current eczema symptoms had almost two more annual consultations of any kind, and children with asthma, either known disease ever or current symptoms, had almost three more annual consultations, compared with children without these diseases (Table 2). Known asthma ever, current asthma symptoms, and current eczema symptoms increased the total health service costs with $>€ 300$ per year, whereas children with known eczema ever, known hay fever ever, or current hay fever symptoms had the same costs as children without. However, children with any atopic disease or symptom had higher medication costs and higher patient shares of medication costs compared with children without (Table S1). Children with known asthma ever or current symptoms of two or more diseases had the highest medication costs of $\sim € 100$ more per year compared with children without and the highest patient share of $\sim € 20$ more per year (Table S1).

\section{Subtypes of health service use}

The use of different health service types among subgroups of children is shown in Table S2. With few exceptions, children with any atopic disease were more likely than children without to use any subtype of health services, also when adjusted for age, sex, and the primary carer's educational level. The odds were highest for children with two or more diseases or symptoms (Table 3). Children with known asthma ever or current asthma symptoms were twice as likely as children without to consult a general practitioner or after-hours duty doctor or to be admitted to hospital. Infection-related hospital admissions accounted for about half of all hospital admissions (Table S2). Though all atopic diseases and symptoms 
Table I Characteristics of annual health service use, prescribed medication, and total costs in various subgroups of children

\begin{tabular}{|c|c|c|c|c|}
\hline \multirow[t]{2}{*}{ Subgroups } & \multirow{2}{*}{$\frac{\mathbf{N}}{\text { Unweighted }}$} & \multirow{2}{*}{$\begin{array}{l}\text { Total health service use } \\
\text { Mean consultations (SEM) }\end{array}$} & \multirow{2}{*}{$\begin{array}{l}\text { Prescribed medication } \\
\text { Mean packages (SEM) }\end{array}$} & \multirow{2}{*}{$\begin{array}{l}\text { Total costs } \\
\text { Mean } €(\text { SEM) }\end{array}$} \\
\hline & & & & \\
\hline Total & 9,720 & $5.79(0.06)$ & $\mathrm{I} .8 \mathrm{I}(0.05)$ & $587(33)$ \\
\hline \multicolumn{5}{|l|}{ Sex } \\
\hline Female & 4,890 & $5.78(0.09)$ & $\mathrm{I} .67(0.05)$ & $602(55)$ \\
\hline Male & 4,830 & $5.64(0.09)$ & $1.95(0.09)$ & $572(35)$ \\
\hline \multicolumn{5}{|l|}{ Age (years) } \\
\hline 3 & 3,433 & $7.35(0.11)$ & $1.95(0.05)$ & $567(43)$ \\
\hline 6 & 2,503 & $5.09(0.10)$ & $1.54(0.10)$ & $513(39)$ \\
\hline 11 & 2,070 & $4.22(0.11)$ & $1.49(0.09)$ & $416(25)$ \\
\hline 15 & $1,7 \mid 4$ & $5.45(0.16)$ & $2.32(0.18)$ & $946(150)$ \\
\hline \multicolumn{5}{|c|}{ Primary carer's education } \\
\hline Master & 2,591 & $5.50(0.1 \mathrm{I})$ & I.7I (0.08) & $506(6 I)$ \\
\hline Bachelor & 3,173 & $5.75(0.10)$ & $1.68(0.06)$ & $560(53)$ \\
\hline Vocational & $\mathrm{I}, 777$ & $6.02(0.14)$ & $2.14(0.18)$ & $737(110)$ \\
\hline School & 1,959 & $6.09(0.14)$ & $1.90(0.10)$ & $620(50)$ \\
\hline \multicolumn{5}{|l|}{ Eczema } \\
\hline Known disease ever & $\mathrm{I}, 583$ & $6.91(0.16)$ & $2.51(0.11)$ & 704 (94) \\
\hline Current symptoms & 927 & $7.56(0.21)$ & $2.90(0.15)$ & $908(167)$ \\
\hline \multicolumn{5}{|l|}{ Asthma } \\
\hline Known disease ever & 697 & $7.80(0.28)$ & $4.36(0.44)$ & $877(86)$ \\
\hline Current symptoms & 1,123 & $8.50(0.21)$ & $3.65(0.26)$ & $1,053(148)$ \\
\hline \multicolumn{5}{|l|}{ Hay fever } \\
\hline Known disease ever & 858 & $6.40(0.23)$ & $2.98(0.22)$ & $732(85)$ \\
\hline Current symptoms ${ }^{\mathrm{a}}$ & 1,059 & $5.88(0.19)$ & $2.94(0.3 \mathrm{I})$ & $652(64)$ \\
\hline \multicolumn{5}{|c|}{ Known atopic disease ever } \\
\hline None & 6,883 & $5.4 I(0.06)$ & $\mathrm{I} .44(0.04)$ & $537(39)$ \\
\hline One & 1,904 & $6.54(0.14)$ & $2.40(0.16)$ & $702(86)$ \\
\hline Two or more & 466 & $7.49(0.33)$ & $3.86(0.28)$ & $803(84)$ \\
\hline \multicolumn{5}{|c|}{ Current symptoms of atopic disease } \\
\hline None & 6,918 & $5.28(0.06)$ & $\mathrm{I} .4 \mathrm{I}(0.04)$ & $515(37)$ \\
\hline One & 2,063 & $6.99(0.14)$ & $2.57(0.12)$ & $661(52)$ \\
\hline Two or more ${ }^{b}$ & 474 & $8.11(0.33)$ & $4.37(0.57)$ & $1,348(3 \mid 5)$ \\
\hline
\end{tabular}

Notes: ${ }^{a}$ Not measured for children aged 3 years. ${ }^{b}$ For children aged 3 years, symptoms of up to two diseases could be reported.

Abbreviation: SEM, standard error of the mean.

increased the odds of consulting an atopic disease-relevant specialist, less than half of the children with eczema, asthma, and hay fever had seen a specialist the latest year (Table S2). For atopic disease-related consultations, we found too few cases to conduct reliable analyses. Only 80 children consulted an outpatient hospital, eight children visited an emergency department, and 45 children were admitted to the hospital due to an atopic disease.

\section{Subtypes of prescribed medication}

The use of prescribed medication subtypes among subgroups of children is shown in Table S3. One out of three children with known eczema ever or current eczema symptoms used prescribed skin medication, and almost half of the children with known asthma ever or current asthma symptoms used respiratory medication. Children with current symptoms of eczema, asthma, or hay fever, and children with known asthma ever used slightly more anti-infective medication compared with children without (Table S3), also when adjusted for age, sex, and the primary carer's educational level (not shown).

\section{Discussion}

We found that children with atopic diseases used health services and prescribed medication more than children without atopic diseases, both in total and for most subtypes of health services.

This study is the first to examine health care use in children with hay fever and contributes new, detailed data on the increased health care use associated with eczema, asthma, and hay fever in a representative sample of Danish children with access to universal health care. Our findings support the hypothesis that childhood atopic disease increases the total health service use and health service costs, beyond the atopy-related services. Of note, there was an increased risk of hospital admission due to infections and increased use of 
Table 2 Annual health service use and costs among children with eczema, asthma, and hay fever compared with children without

\begin{tabular}{|c|c|c|c|}
\hline \multirow[t]{2}{*}{ Atopic disease } & \multirow{2}{*}{$\begin{array}{l}\text { Total health service use } \\
\text { (consultations) } \\
\text { Mean difference }(95 \% \mathrm{Cl})\end{array}$} & \multirow{2}{*}{$\begin{array}{l}\text { Use of prescribed medication } \\
\text { (packages) } \\
\text { Mean difference }(95 \% \mathrm{Cl})\end{array}$} & \multirow{2}{*}{$\begin{array}{l}\text { Total costs }(€) \\
\text { Mean difference }(95 \% \mathrm{Cl})\end{array}$} \\
\hline & & & \\
\hline \multicolumn{4}{|l|}{ Eczema } \\
\hline Known disease ever & $1.28(0.93-1.64)$ & $0.86(0.63-1.09)$ & $174(-22$ to 370$)$ \\
\hline Current symptoms & $1.77(1.29-2.26)$ & $1.33(0.97-1.70)$ & $459(48-87 I)$ \\
\hline \multicolumn{4}{|l|}{ Asthma } \\
\hline Known disease ever & $2.75(2.13-3.36)$ & $2.29(1.74-2.84)$ & $309(85-533)$ \\
\hline Current symptoms & $2.53(2.08-2.98)$ & $1.69(1.36-2.01)$ & $586(240-932)$ \\
\hline \multicolumn{4}{|l|}{ Hay fever } \\
\hline Known disease ever & I.II (0.60-I.62) & $\mathrm{I} .08(0.64-1.5 \mathrm{I})$ & $110(-126$ to 346$)$ \\
\hline Current symptoms ${ }^{\mathrm{a}}$ & $1.21(0.74-1.67)$ & $1.13(0.65-1.62)$ & $77(-142$ to 297$)$ \\
\hline \multicolumn{4}{|l|}{ Known atopic disease ever } \\
\hline One vs none & $1.24(0.90-1.58)$ & $0.77(0.54-1.00)$ & $127(-46$ to 300$)$ \\
\hline Two or more vs none & $2.54(1.82-3.25)$ & $2.14(1.63-2.65)$ & $278(3-552)$ \\
\hline \multicolumn{4}{|c|}{ Current atopic symptoms of atopic disease } \\
\hline One vs none & $1.60(1.28-1.93)$ & $1.03(0.76-1.30)$ & $188(46-329)$ \\
\hline Two or more vs none $e^{b}$ & $3.20(2.48-3.92)$ & $2.40(1.83-2.96)$ & $897(237-1,555)$ \\
\hline
\end{tabular}

Notes: All analyses were adjusted for sex, age, and primary carer's educational level. Reference categories: known disease ever vs children without the atopic condition ever;

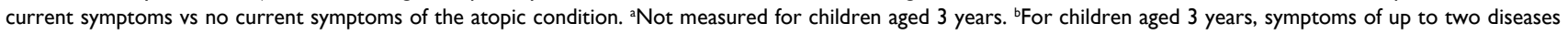
could be reported.

Abbreviation: $\mathrm{Cl}$, confidence interval.

Table 3 Subtypes of annual health service use among children with eczema, asthma, and hay fever compared with children without

\begin{tabular}{|c|c|c|c|c|c|c|c|}
\hline Atopic disease & $\begin{array}{l}\text { General } \\
\text { practitioner }\end{array}$ & $\begin{array}{l}\text { Atopic disease- } \\
\text { relevant } \\
\text { specialist }\end{array}$ & $\begin{array}{l}\text { Outpatient } \\
\text { hospital }\end{array}$ & $\begin{array}{l}\text { After-hours } \\
\text { duty doctor }\end{array}$ & $\begin{array}{l}\text { Emergency } \\
\text { department }\end{array}$ & $\begin{array}{l}\text { Hospital } \\
\text { admission }\end{array}$ & $\begin{array}{l}\text { Hospital } \\
\text { admission due } \\
\text { to infection } \\
\end{array}$ \\
\hline & OR $(95 \% \mathrm{CI})$ & OR $(95 \% \mathrm{Cl})$ & OR (95\% CI) & OR $(95 \% \mathrm{CI})$ & OR (95\% Cl) & OR $(95 \% \mathrm{CI})$ & OR $(95 \% \mathrm{CI})$ \\
\hline \multicolumn{8}{|l|}{ Eczema } \\
\hline $\begin{array}{l}\text { Known disease } \\
\text { ever }\end{array}$ & $1.73(1.43-2.10)$ & $\mathrm{I} .60(\mathrm{I} .4 \mathrm{I}-\mathrm{I} .8 \mathrm{I})$ & $1.25(1.05-1.48)$ & $1.17(1.03-1.33)$ & $1.04(0.89-1.22)$ & $1.14(0.88-1.49)$ & $1.38(0.93-2.04)$ \\
\hline $\begin{array}{l}\text { Current } \\
\text { symptoms }\end{array}$ & $2.26(1.7-3.00)$ & $1.88(1.6 \mathrm{I}-2.19)$ & $1.17(0.95-1.44)$ & $1.30(1.11-1.53)$ & $1.21(1.00-1.47)$ & $1.46(1.09-1.97)$ & $1.02(0.66-1.58)$ \\
\hline \multicolumn{8}{|l|}{ Asthma } \\
\hline $\begin{array}{l}\text { Known disease } \\
\text { ever }\end{array}$ & $2.35(1.77-3.13)$ & $1.37(1.14-1.65)$ & $1.72(1.38-2.14)$ & $1.93(1.59-2.33)$ & $1.18(0.95-1.48)$ & $2.03(1.44-2.86)$ & $2.07(1.23-3.48)$ \\
\hline $\begin{array}{l}\text { Current } \\
\text { symptoms }\end{array}$ & $2.00(1.54-2.60)$ & $1.32(1.14-1.52)$ & $1.80(1.51-2.15)$ & $1.71(1.47-1.99)$ & $1.26(1.06-1.50)$ & $2.21(1.73-2.82)$ & $2.41(1.72-3.37)$ \\
\hline \multicolumn{8}{|l|}{ Hay fever } \\
\hline $\begin{array}{l}\text { Known disease } \\
\text { ever }\end{array}$ & $\mathrm{I} .44(1.14-\mathrm{I} .82)$ & $1.22(1.03-1.46)$ & $1.26(1.01-1.57)$ & $1.34(1.12-1.60)$ & $1.13(0.91-1.40)$ & $1.65(1.16-2.33)$ & $1.76(1.01-3.05)$ \\
\hline $\begin{array}{l}\text { Current } \\
\text { symptoms }\end{array}$ & $\mathrm{I} .64(1.35-2.0 \mathrm{I})$ & $1.27(1.08-1.50)$ & $1.24(1.00-1.53)$ & $1.37(1.15-1.64)$ & $1.16(0.94-1.42)$ & $1.6 \mathrm{I}(1.1 \mathrm{I}-2.35)$ & $1.72(0.89-3.30)$ \\
\hline \multicolumn{8}{|c|}{ Known atopic disease ever } \\
\hline One vs none & $1.60(1.34-1.91)$ & $1.39(1.23-1.57)$ & $1.15(0.98-1.36)$ & $1.28(1.13-1.45)$ & $1.10(0.94-1.28)$ & $1.28(1.00-1.65)$ & $1.74(1.22-2.48)$ \\
\hline $\begin{array}{l}\text { Two or more } \\
\text { vs none }\end{array}$ & $2.68(1.91-3.76)$ & $1.78(1.43-2.22)$ & I.7I (I.29-2.25) & $1.65(1.32-2.07)$ & I. $14(0.87-1.50)$ & $1.92(1.23-3.01)$ & $1.62(0.68-3.83)$ \\
\hline \multicolumn{8}{|c|}{ Current symptoms of atopic disease } \\
\hline One vs none & $1.73(1.46-2.04)$ & $1.43(1.27-1.61)$ & $1.30(1.12-1.52)$ & $1.38(1.22-1.55)$ & $1.24(1.07-1.43)$ & $1.79(\mathrm{I} .42-2.26)$ & $1.91(1.36-2.68)$ \\
\hline $\begin{array}{l}\text { Two or more } \\
\text { vs none }{ }^{b}\end{array}$ & $2.97(1.99-4.42)$ & I.8I (I.46-2.24) & $1.89(1.45-2.47)$ & $2.03(1.62-2.55)$ & $1.26(0.96-1.66)$ & $2.5 \mathrm{I}(1.69-3.72)$ & $1.99(1.07-3.69)$ \\
\hline
\end{tabular}

Notes: All analyses were adjusted for sex, age, and primary carer's educational level. Reference categories: known disease ever vs children without the atopic condition ever; current symptoms vs no current symptoms of the atopic condition. ${ }^{\mathrm{a} N o t}$ measured for children aged 3 years. ${ }^{\mathrm{b}}$ For children aged 3 years, symptoms of up to two diseases could be reported.

Abbreviations: $\mathrm{OR}$, odds ratio; $\mathrm{Cl}$, confidence interval. 
anti-infective medication among children with atopic disease compared with other children, reflecting the burden of infectious disease comorbidity.

Our findings are in agreement with the French study of children with atopic eczema ${ }^{5}$ and the Canadian, German, and American studies of children with asthma ${ }^{6-8}$ described in the "Introduction" section, and extend their findings by describing total health service use, but also more detailed subtypes of health services, medications, and costs. Furthermore, our results confirm other studies showing that far from all children with atopic disease get specialized treatment, even though it is recommended. ${ }^{18-20}$

The strengths of this study include complete data on detailed, individual-level register-based measures of all health services, costs, and educational level. Data from registries are generally considered reliable and without recall bias. Secondly, we used validated measures of atopic diseases, both known disease ever and current symptoms regardless of diagnosis, which is important when examining diseases expected to be underdiagnosed. Thirdly, we had a relatively homogenous study population in respect to accessibility of health services free of charge, and supply of facilities such as specialists and emergency departments, and with regular health examinations of children at different ages.

Limitations include lack of objective measures of atopic disease such as lung function or atopic disease tests and of severity measures. The variable "known disease ever" may include some children not currently affected, and a proportion of the children with "current symptoms of disease" may be undiagnosed. Our definitions may thus be a mixture of different phenotypes with different health care needs. This may in part explain the relatively low proportion of children receiving specialized treatment, and affect our estimates toward the null. Secondly, whereas register data are considered reliable concerning frequency, date, and duration of contacts, data from the primary health care sector are unspecific regarding the indication of health services. Therefore, we could not assess atopic disease-related primary health care consultations. Also, in analyses of cost of each specific disease, there may be a contribution of cost from other conditions. Moreover, the registers only contain prescribed medication, not over-the-counter medication such as many skin products and hay fever products, which are absent in our measures of medication use and costs. Every third prescription had no defined daily dose, so instead we used packages as unit, which is less precise. Thirdly, nonresponse bias is possible despite the detailed weighting for nonresponse. Even if a high degree of representativity is achieved, the results may only be applicable to children in the Danish health care system. Finally, we were limited by the cross-sectional design with no possibility to determine causality. We expect a circular relation, where atopic disease increases health service use, and at the same time, health service use increases the likelihood of known disease. We find the same tendencies when measuring known disease ever and current symptoms. We do, however, find a tendency toward lower use of health services among children with symptoms compared with children with known disease ever. This suggests a potential for improving early and sufficient detection of atopic diseases in children.

\section{Conclusion}

Eczema, asthma, and hay fever increased the use of most health services and prescribed medication in children. Children with two or more atopic diseases used most health services and medication and had the highest costs.

\section{Acknowledgments}

The authors would like to thank the children and their parents who participated, and the City of Copenhagen for conducting the child health survey. This research received no specific grant from any funding agency in the public, commercial, or nonprofit sectors.

\section{Disclosure}

The authors report no conflicts of interest in this work.

\section{References}

1. Mak H, Johnston P, Abbey H, Talamo RC. Prevalence of asthma and health service utilization of asthmatic children in an inner city. J Allergy Clin Immunol. 1982;70(5):367-372.

2. Zhang T, Smith MA, Camp PG, Carleton BC. High use of health services in patients with suboptimal asthma drug regimens: a population-based assessment in British Columbia, Canada. Pharmacoepidemiol Drug Saf. 2013;22(7):744-751.

3. Chang J, Freed GL, Prosser LA, et al. Comparisons of health care utilization outcomes in children with asthma enrolled in private insurance plans versus medicaid. J Pediatr Health Care. 2014;28(1):71-79.

4. Moncrief T, Beck AF, Simmons JM, Huang B, Kahn RS. Single parent households and increased child asthma morbidity. J Asthma. 2014;51(3):260-266.

5. Misery L, Ansolabehere X, Grandfils N, Georgescu V, Taieb C. Nineyear follow-up of children with atopic dermatitis by general practitioners. Dermatology. 2014;228(4):344-349.

6. Maziak W, von Mutius E, Keil U, et al. Predictors of health care utilization of children with asthma in the community. Pediatr Allergy Immunol. 2004;15(2):166-171.

7. To T, Dell S, Tassoudji M, Wang C. Health outcomes in low-income children with current asthma in Canada. Chronic Dis Can. 2009;29(2):49-55.

8. Jin Y, Seiber EE, Ferketich AK. Secondhand smoke and asthma: what are the effects on healthcare utilization among children? Prev Med. 2013;57(2):125-128.

9. Thygesen LC, Daasnes C, Thaulow I, Bronnum-Hansen H. Introduction to Danish (nationwide) registers on health and social issues: structure, access, legislation, and archiving. Scand J Public Health. 2011;39(7 Suppl):12-16. 
10. Hammer-Helmich L, Linneberg A, Thomsen SF, Glumer C. Association between parental socioeconomic position and prevalence of asthma, atopic eczema and hay fever in children. Scand J Public Health. 2014;42(2):120-127.

11. Pedersen CB. The Danish Civil Registration System. Scand J Public Health. 2011;39(7 Suppl):22-25.

12. Asher MI, Keil U, Anderson HR, et al. International Study of Asthma and Allergies in Childhood (ISAAC): rationale and methods. Eur Respir J. 1995;8(3):483-491.

13. Williams HC, Burney PG, Pembroke AC, Hay RJ. The U.K. Working Party's Diagnostic Criteria for Atopic Dermatitis. III. Independent hospital validation. Br J Dermatol. 1994;131(3):406-416.

14. Andersen JS, Olivarius Nde F, Krasnik A. The Danish National Health Service Register. Scand J Public Health. 2011;39(7 Suppl):34-37.

15. Kruse M, Christiansen T. Register-based studies of healthcare costs Scand J Public Health. 2011;39(7 Suppl):206-209.
16. Fangel S, Linde PC, Thorsted BL. Nye problemer med repræsentativitet i surveys, som opregning med registre kan reducere. [New problems with survey representativity, which enumeration with registers is able to reduce]. Metode og Data. 2007;93:14-26. Danish.

17. Särndal C-E, Swensson B, Wretman J. Model Assisted Survey Sampling. Springer-Verlag, New York; 1992.

18. Flores G, Snowden-Bridon C, Torres S, et al. Urban minority children with asthma: substantial morbidity, compromised quality and access to specialists, and the importance of poverty and specialty care. J Asthma. 2009;46(4):392-398.

19. Moth G, Schiotz PO, Vedsted P. A Danish population-based cohort study of newly diagnosed asthmatic children's care pathway - adherence to guidelines. BMC Health Serv Res. 2008;8:130.

20. Nolte H, Nepper-Christensen S, Backer V. Unawareness and undertreatment of asthma and allergic rhinitis in a general population. Respir Med. 2006;100(2):354-362. 


\section{Supplementary materials}

Table SI Annual medication costs and patient share of medication costs among children with eczema, asthma, or hay fever compared with children without

\begin{tabular}{|c|c|c|}
\hline \multirow[t]{2}{*}{ Atopic disease } & Medication costs $(€)$ & \multirow{2}{*}{$\begin{array}{l}\text { Patient share of medication costs }(€) \\
\text { Mean difference }(95 \% \mathrm{Cl})\end{array}$} \\
\hline & Mean difference $(95 \% \mathrm{Cl})$ & \\
\hline \multicolumn{3}{|l|}{ Eczema } \\
\hline Known disease ever & $19.90(8.88-30.91)$ & $6.93(4.65-9.20)$ \\
\hline Current symptoms & 33.27 (13.16-53.37) & $10.80(6.33-15.27)$ \\
\hline \multicolumn{3}{|l|}{ Asthma } \\
\hline Known disease ever & 92.21 (55.27-129.16) & $20.35(15.47-25.24)$ \\
\hline Current symptoms & $55.46(35.4 I-75.50)$ & $17.90(12.99-22.82)$ \\
\hline \multicolumn{3}{|l|}{ Hay fever } \\
\hline Known disease ever & $26.56(2.05-51.06)$ & $8.27(4.72-11.82)$ \\
\hline Current symptoms ${ }^{\mathrm{a}}$ & $46.43(15.69-77.18)$ & $9.15(4.93-13.38)$ \\
\hline \multicolumn{3}{|l|}{ Known atopic disease ever } \\
\hline One vs none & $21.91(6.94-36.88)$ & $5.7 \mid(3.52-7.89)$ \\
\hline Two or more vs none & $63.23(39.02-87.44)$ & 20.54 (14.79-26.29) \\
\hline \multicolumn{3}{|c|}{ Current symptoms of atopic disease } \\
\hline One vs none & $25.99(9.96-42.01)$ & $6.61(4.73-8.50)$ \\
\hline Two or more vs none ${ }^{b}$ & $95.83(55.31-136.35)$ & 28.57 (I8.64-38.49) \\
\hline
\end{tabular}

Notes: All analyses were adjusted for sex, age, and primary carer's educational level. Reference categories: known disease ever vs children without the atopic condition ever; current symptoms vs no current symptoms of the atopic condition. ${ }^{a}$ Not measured for children aged 3 years. ${ }^{b}$ For children aged 3 years, symptoms of up to two diseases could be reported.

Abbreviation: $\mathrm{Cl}$, confidence interval.

Table S2 Annual use of different types of health services among various subgroups of children

\begin{tabular}{|c|c|c|c|c|c|c|c|c|}
\hline Atopic disease & $\begin{array}{l}\text { General } \\
\text { practitioner }\end{array}$ & $\begin{array}{l}\text { General } \\
\text { practitioner }\end{array}$ & $\begin{array}{l}\text { Atopic disease- } \\
\text { relevant } \\
\text { specialist }\end{array}$ & $\begin{array}{l}\text { Outpatient } \\
\text { hospital }\end{array}$ & $\begin{array}{l}\text { After-hours } \\
\text { duty doctor }\end{array}$ & $\begin{array}{l}\text { Emergency } \\
\text { department }\end{array}$ & $\begin{array}{l}\text { Hospital } \\
\text { admission }\end{array}$ & $\begin{array}{l}\text { Hospital } \\
\text { admission } \\
\text { due to } \\
\text { infection }\end{array}$ \\
\hline & Mean (SD) & $\%$ & $\%$ & $\%$ & $\%$ & $\%$ & $\%$ & $\%$ \\
\hline Total & $3.45(3.36)$ & 83.8 & 28.8 & 13.8 & 36.7 & 16.8 & 5.2 & 2.2 \\
\hline \multicolumn{9}{|l|}{ Sex } \\
\hline Female & $3.5 \mathrm{I}(3.50)$ & 83.1 & 26.3 & 12.5 & 36.7 & 15.6 & 4.7 & 2.2 \\
\hline Male & $3.22(3.33)$ & 81.0 & 27.1 & 15.4 & 36.6 & 20.6 & 5.9 & 2.1 \\
\hline \multicolumn{9}{|l|}{ Age (years) } \\
\hline 3 & $4.39(3.60)$ & 92.3 & 29.7 & 13.4 & 54.9 & 19.1 & 7.3 & 3.6 \\
\hline 6 & $2.95(2.93)$ & 81.2 & 27.6 & 13.1 & 38.2 & 14.1 & 4.9 & 2.2 \\
\hline 11 & $2.32(2.79)$ & 70.4 & 24.7 & 13.7 & 22.7 & 19.1 & 3.7 & 0.9 \\
\hline 15 & 3.34 (3.79) & 79.1 & 23.1 & 16.3 & 21.0 & 20.6 & 4.5 & 0.9 \\
\hline \multicolumn{9}{|l|}{ Eczema } \\
\hline $\begin{array}{l}\text { Known disease } \\
\text { ever }\end{array}$ & $4.06(3.53)$ & 89.3 & 37.4 & 15.5 & 40.7 & 17.7 & 5.9 & 2.8 \\
\hline $\begin{array}{l}\text { Current } \\
\text { symptoms }\end{array}$ & $4.47(3.76)$ & 92.6 & 41.5 & 15.3 & 43.7 & 19.3 & 7.1 & 2.8 \\
\hline \multicolumn{9}{|l|}{ Asthma } \\
\hline $\begin{array}{l}\text { Known disease } \\
\text { ever }\end{array}$ & $4.52(4.16)$ & 89.8 & 35.0 & 21.5 & 40.2 & 19.1 & 8.0 & 3.3 \\
\hline $\begin{array}{l}\text { Current } \\
\text { symptoms }\end{array}$ & 4.95 (3.96) & 92.3 & 36.6 & 20.7 & 49.1 & 20.2 & 10.4 & 5.3 \\
\hline \multicolumn{9}{|l|}{ Hay fever } \\
\hline $\begin{array}{l}\text { Known disease } \\
\text { ever }\end{array}$ & $3.70(3.66)$ & 85.1 & 32.8 & 17.5 & 32.9 & 18.4 & 6.5 & 2.2 \\
\hline $\begin{array}{l}\text { Current } \\
\text { symptoms }\end{array}$ & $3.48(3.62)$ & 82.5 & 31.6 & 16.4 & 27.0 & 17.3 & 4.8 & 1.6 \\
\hline
\end{tabular}


Table S2 (Continued)

\begin{tabular}{|c|c|c|c|c|c|c|c|c|}
\hline Atopic disease & $\begin{array}{l}\text { General } \\
\text { practitioner }\end{array}$ & $\begin{array}{l}\text { General } \\
\text { practitioner }\end{array}$ & $\begin{array}{l}\text { Atopic disease- } \\
\text { relevant } \\
\text { specialist }\end{array}$ & $\begin{array}{l}\text { Outpatient } \\
\text { hospital }\end{array}$ & $\begin{array}{l}\text { After-hours } \\
\text { duty doctor }\end{array}$ & $\begin{array}{l}\text { Emergency } \\
\text { department }\end{array}$ & $\begin{array}{l}\text { Hospital } \\
\text { admission }\end{array}$ & $\begin{array}{l}\text { Hospital } \\
\text { admission } \\
\text { due to } \\
\text { infection } \\
\end{array}$ \\
\hline & Mean (SD) & $\%$ & $\%$ & $\%$ & $\%$ & $\%$ & $\%$ & $\%$ \\
\hline \multicolumn{9}{|c|}{ Known atopic disease ever } \\
\hline None & $3.24(3.19)$ & 82.3 & 26.7 & 12.7 & 36.2 & 16.3 & 4.8 & 1.9 \\
\hline One & $3.87(3.66)$ & 87.3 & 33.6 & 15.4 & 38.5 & 17.7 & 5.9 & 3.2 \\
\hline Two or more & $4.32(3.70)$ & 89.9 & 39.1 & 20.0 & 37.1 & 19.1 & 6.9 & 1.7 \\
\hline \multicolumn{9}{|c|}{ Current symptoms of atopic disease } \\
\hline None & $3.16(3.14)$ & 82.2 & 26.6 & 12.6 & 35.5 & 15.9 & 4.3 & 1.7 \\
\hline One & $4.14(3.73)$ & 88.0 & 34.1 & 15.9 & 40.3 & 19.0 & 7.2 & 3.5 \\
\hline Two or more ${ }^{b}$ & $4.69(4.04)$ & 91.8 & 41.6 & 21.3 & 40.3 & 18.4 & 8.4 & 3.0 \\
\hline
\end{tabular}

Notes: a Not measured for children aged 3 years. ${ }^{b}$ For children aged 3 years, symptoms of up to two diseases could be reported. Abbreviation: SD, standard deviation.

Table S3 Use of skin medication, respiratory medication, and anti-infective medication in 2009 among various subgroups of children

\begin{tabular}{|c|c|c|c|}
\hline Subgroup & $\begin{array}{l}\text { Skin medication } \\
\%\end{array}$ & $\begin{array}{l}\text { Respiratory medication } \\
\%\end{array}$ & $\begin{array}{l}\text { Anti-infective medication } \\
\%\end{array}$ \\
\hline Total & 14.0 & 12.7 & 37.6 \\
\hline \multicolumn{4}{|l|}{ Sex } \\
\hline Female & 13.6 & 10.9 & 37.6 \\
\hline Male & 14.4 & 14.5 & 37.5 \\
\hline \multicolumn{4}{|l|}{ Age (years) } \\
\hline 3 & 17.8 & 15.1 & 53.5 \\
\hline 6 & 13.2 & 10.3 & 35.1 \\
\hline 11 & 10.4 & 11.2 & 22.6 \\
\hline 15 & 11.9 & 13.2 & 27.4 \\
\hline \multicolumn{4}{|l|}{ Eczema } \\
\hline Known disease ever & 27.9 & 20.3 & 40.1 \\
\hline Current symptoms & 38.5 & 20.5 & 43.0 \\
\hline \multicolumn{4}{|l|}{ Asthma } \\
\hline Known disease ever & 17.6 & 46.2 & 39.3 \\
\hline Current symptoms & 18.3 & 42.0 & 47.6 \\
\hline \multicolumn{4}{|l|}{ Hay fever } \\
\hline Known disease ever & 17.8 & 33.3 & 33.3 \\
\hline Current symptoms ${ }^{\mathrm{a}}$ & 15.5 & 24.6 & 30.2 \\
\hline \multicolumn{4}{|c|}{ Known atopic disease ever } \\
\hline None & 11.2 & 8.0 & 37.1 \\
\hline One & 21.3 & 19.1 & 39.9 \\
\hline Two or more & 25.3 & 45.7 & 35.2 \\
\hline \multicolumn{4}{|c|}{ Current symptoms of atopic disease } \\
\hline None & 11.2 & 7.5 & 36.6 \\
\hline One & 20.3 & 23.7 & 40.7 \\
\hline Two or more ${ }^{b}$ & 29.5 & $4 I .1$ & 39.9 \\
\hline
\end{tabular}

Notes: aNot measured for children aged 3 years. ${ }^{b}$ For children aged 3 years, symptoms of up to two diseases could be reported.

\section{Clinical Epidemiology}

\section{Publish your work in this journal}

Clinical Epidemiology is an international, peer-reviewed, open access, online journal focusing on disease and drug epidemiology, identification of risk factors and screening procedures to develop optimal preventative initiatives and programs. Specific topics include: diagnosis, prognosis, treatment, screening, prevention, risk factor modification,

Submit your manuscript here: https://www.dovepress.com/clinical-epidemiology-journal systematic reviews, risk and safety of medical interventions, epidemiology and biostatistical methods, and evaluation of guidelines, translational medicine, health policies and economic evaluations. The manuscript management system is completely online and includes a very quick and fair peer-review system, which is all easy to use. 